\section{Fermented Foods and Obesity}

\section{Peter Orji Uvere*}

Department of Food Science and Technology, University of Nigeria, Nigeria

Fermented foods are foods produced by the desirable modification of food properties by microorganisms and enzymes without complete stabilisation of the nutrients to carbon dioxide, water and energy. It results in a significant increase in the soluble fraction of a food, but the anti-nutritional factors decline. The concentration of vitamins, minerals and protein appear to increase when measured on a dry weight basis. This makes fermentation an important option for food processing, although some authors argue that no improvement is recorded in the nutritive value of meat, fish, vegetables and fruits, safety of fruits, stability of legumes and cereals and safety of cereals.

These observations run counter to the persistent use of fermented foods in traditional settings where, obesity is hardly an issue, pointing to both dietary and lifestyle influences. The obesity phenomenon crept in from the more developed world where technological advancements have increased the sedentary lifestyle and put more food processed into diverse forms on the table. Apart from the full meals, this has increased the snacking habit and encouraged the accumulation of energy.

In traditional societies where obesity is encouraged (as in Calabar in Nigeria), girls of marriageable age are 'quarantined' and deliberately fed to improve fleshing, a good indication of well being which will be acceptable to the would-be husband. Added to this is the Japanese sumo tradition which encourages the addition of weight by Rikishis so as to compete more effectively. Beyond these cases and a few which are purely genetic, traditional societies are mainly populated by slimmer individuals.

The overwhelming point is that the use of fermented foods in traditional societies may help to control obesity in these societies. There is therefore, a need to evaluate the effect of fermented foods in a more controlled setting.
*Corresponding author: Peter Orii Uvere, Department of Food Science and Technology, University of Nigeria, Nigeria, Tel. 234-80-64714235, 234-8945274928, Fax 234-042-770644; E-mail: peter.uvere@unn.edu.ng

Received December 03, 2012; Accepted December 05, 2012; Published December 08, 2012

Citation: Uvere PO (2012) Fermented Foods and Obesity. Ferment Techno 1:e116. doi:10.4172/2167-7972.1000e116

Copyright: ( 2012 Uvere PO. This is an open-access article distributed under the terms of the Creative Commons Attribution License, which permits unrestricted use, distribution, and reproduction in any medium, provided the original author and source are credited. 